\title{
Konsep Teologi Perspektif Para Rasul
}

\author{
Suharsono \\ Sekolah Tinggi Ilmu Tarbiyah Muhammadiyah Paciran, Indonesia \\ Email: Sonosuhar22@gmail.com
}

\begin{abstract}
Every Muslim is required to believe that Islam is the true religion. Even though, the prohibition against demeaning other religions has to be carried out. Moreover, it hurts the adherents of other religions outside Islam. The humiliate attitude towards other religions and faith actually shows that Islam is not a noble religion. Whereas the command of Allah SWT in the Qur'an and the spirit brought by the prophet Muhammad SAW is rahmatan lil 'alamin (the mercy for the whole world).

Muslims make the prophet Muhammad SAW as the role model in social life especially in religion. He was the role model of a leader who had charismatic character and able to made peaceful and pleasant feelings for people he led even though they had different faith. This shows that there is no compulsion in having religion. People are free to choose their religion and faith which means that there is no arrogance in theology.

In theology, many groups emerged, and each of them brought their own arguments. However the clear concept in Islam's view is the theology which is based on the genuineness of teachings brought by the Prophets. So, no wonder if all emerged groups claimed that their opinion was the most correct arguments, that is the Ahlu Sunnah Waljama'ah.
\end{abstract}

Keyword: Theology, Rosul

\section{Pendahuluan}

Kemuliaan suatu Ilmu sangat ditentukan oleh obyek pembahasannya, Ibnu Qoyyim berkata “Sharofu al-ilmi tabi'un li sharafi ma'lûmiĥ̃’(mulianya ilmu itu mengikut mulianya yang dipelajari). (1994, 1: 87). Teologi membicarakan tentang Tuhan, sementara yang lain seperti biologi membicarakan tentang makhluk hidup, sosiologi membicarakan tentang masyarakat, psikologi membicarakan tentang jiwa manusia dan lain-lainya. Pembahasannya tentang pencipta bukan ciptaan, sesembahan bukan yang menyembah yaitu Allah ta'ala tentu lebih mulia dan menyamakanNya dengan yang selainNya adalah kedhaliman.

Manusia sejak dalam kandungan seorang ibu telah mengakui Tuhan, Allah berfirman alastu biRabbikum qâlu balâ shahidnâ (bukankah Aku Tuhan kalian, mereka menjawab tentu kami telah memberikan kesaksian). (QS. 7: 172). Adampun mengakui hal itu dan ta'at kepadaNya bahkan Iblis menetapkan keberadaanNya. Mereka semua masih dalam keadaan monotheisme tidak mengimani Tuhan kecuali Allah. 
Catatan sejarah membuktikan bahwa ilmu ketuhanan dan penyelewengan masalah ketuhanan terjadi dimasa Nabi Nuh, sebagian manusia telah membuat berhala yang diberi nama Waddan, Suwâ'an, Yaghûts, ya'ûq dan Nasra (QS. 71: 23; al-Asqolani,1988, 8: 535, Muhammad Nur,1995,1: 95-96 ). Sementara Nuh tetap konsisten mengajak tauhid selama 950 tahun. (QS. 29: 14).

Misi Nabi Nuh dilanjutkan para nabi sampai Nabi terakhir Muhammad bin Abdullah, berjumlah 25 yang disebut namanya dalam al-Qur'an. Jumlah mereka semua disebut dalam hadits tsabit dari Abu Dzar; seratus duapuluh empat ribu nabi. (Barjas, 2006: 32). Mereka tidak mengajak umatnya kecuali menetapkan tidak ada sesembahan yang benar kecuali Allah. Allah berfirman: "Dan Kami tidak mengutus seorang rasulpun sebelum kamu melainkan Kami wahyukan kepadanya: "Bahwasanya tidak ada yang berhak disembah (ilâh) kecuali Aku maka hendaklah kalian menyembah Aku".(QS. 21: 25). Para rasul menetapkan Dialah Allah Rabbul'alamin, sesembahan yang benar dan selainNya adalah bathil. (QS. 31: 30).

\section{Konsep Teologi Dalam sejarah Manusia}

\section{Pengertian Ilmu dan Tuhan}

Teologi dari bahasa Yunani; theos berarti tuhan, logos berarti ilmu, jadi teologi maksudnya ilmu tentang Tuhan. Dalam kamus besar bahasa Indonesia; teologi adalah pengetahuan ketuhanan. (2018: 1720).

a. Pengetrtian Ilmu

1). Menurut bahasa

Secara bahasa ilmu adalah tahu lawan daei bodoh dari fi'il 'alima ya'lamu 'ilman...Orang yang mengetahui diktakan 'âlim, jamaknya ulama. Berkata Sibawaih: "ulamâ adalah orang yang tidak berkata kecuali dia dalam keadaan berilmu"...Adapun Orang yang baru dalam memasuki ilmu disebut muta'allim bukan 'âlim. (Ibnu al-Mandzur,1990, 12: 417).

2). Menurut Istilah

Ibnu 'Uthaimin berkata: "Ilmu adalah Mengetahui sesuatu sebagaimana kenyataannya dengan pengetahuan yang pasti”.

Perkataan dengan "mengetahui sesuatu", maka yang tidak mengetahui secara utuh disebut bodoh ringan/jahlun basith, lalu dengan perkataan "sebagaimana kenyataannya" maka pengetahuan yang menyelisihi 
kenyataanya disebut bodoh kwadrat/ Jahlun murakkab, kemudian perkataan "dengan pengetahuan yang pasti" maka pengetahuan yang tidak pasti tidak dinamakan ilmu, jika terjadi terkuatkan di antara dua kemungkinan rajih dan marjuh maka yang kuat/rajih itu disebut dhon, kalau sama kuat disebut Syak, kalau yang tidak kuat disebut Wahm. (Ibnu Uthaimin, 2003:14) Sebagian ahlu al ilmi berkata:" Ilmu adalah perkataan Allah, perkataan UtusanNya dan perkataan shahabat”. ( Al-Safîrîni, 1982, 1:7).

b. Pengertian Tuhan

1). Menurut bahasa Indonesia

Tuhan adalah Sesuatu yang diyakini, dipuja dan disembah oleh manusia sebagai yang Mahakuasa, Mahaperkasa, dsb. (Kamus besar bahasa Indonesia, 2018: 1781). Jadi Tuhan dalam bahasa Indonesia masih bersifat umum bisa Allah dalam versi umat islam dan bisa berhala atau nama-nama yang lain menurut versi lain.

2). Menurut bahasa Arab

Ada dua kata yang sering diartikan dalam bahasa Indonesia dengan penyebutan Tuhan yaitu;

a). Al-Rabb

Berkatan Ibnu al-Mandzur (1990): “Al-Rabb adalah Allah-azza wa jallaDia pemilik segala sesuatu yang memiliki rububiyah pada semua makhluk dan tidak ada sekutu bagiNya...Tidak dikatakan $a l-R a b b$ (isim ma'rifah) untuk selain Allah kecuali diidhafahkan, (Lisanul al-Arab,1: 399) seperti rabbu al-dar (pemilik rumah).

b). Al-Ilah

Berkatan Ibnu al-Mandzur (1990): : Al-Ilâh adalah Allah-azza wa jalla-. Dan segala sesuatu dari selain Allah yang disembah adalah Ilâh bagi pelakunya, jamaknya Ālihah. Berhala bisa dinamakan ilâh karena pelakunya berkeyakinan dia berhak disembah atau diibadaahi. (Lisanul al-Arab, 13: 467).

Berdasarkan bahasa Arab bahwa Tuhan yang sesungguhnya adalah tidak lain kecuali Allah, Dia adalah Rabb dan Ilâh. Adapun selainNya dipertuhankan dan bisa disebut ilâh, dalam bab inilah kaum musyrikin sejak zaman nabi Nuh tergelincir memalingkan ibadah kepada selain Allah. Allah berfirman:" 
Tidaklah kebanyakan mereka beriman kepada Allah kecuali mereka itu dalam keadaan musyrik". (QS.12: 106). Ibnu Abbas berkata: "Siapa pencipta mereka, langit dan bumi?", Mereka menjawab: "Allah". Itulah iman mereka, sementara mereka memalingkan ibadah (mengilâhkan) kepada selain Allah (itulah kemusyrikan mereka)". (Suyuthi, 1990, 2:75).

3). Menurut al-Qur'an

Dalam al-Qur'an ada penyebutan; Allah Rabbu al- 'âlamin. (QS. 1: 1), Rabbu al-nâs. (QS.114:1) dan Ilâhu al-nâs (QS.114:1), Allah lâilûha illa huwa. (QS.2: 255).

Berdasarkan al-Qur'an bahwa Tuhan yang sesungguhnya adalah tuhan pencipta dan pemilik manusia dan alam ini serta berhak diibadahi dan disembah, itu tidak lain kecuali Allah, Adapun selainNya tidak berhak menyandang predikat sebagai Tuhan dan tidak berhak disembah dan diibadahi walaupun dipertuhankan.

Adapun sesuatu yang dipertuhankan dalam al-Qur'an ada disebut dan diungkapkan $r a b b$ seperti kisah ahlu kitab yang menjadikan tokoh agamanya sebagai arbâban (QS. 9:31) dan ungkapan ilâh seperti menjadikan hawa nafsu sebagai ilâhan (QS. 25:43), perkataan kaum Musa kepadanya buatkanlah untuk kami ilâh sebagaimana mereka punya ilâh (QS. 7: 138).

c. Kesimpulan dan Batasan masalah

Dari beberapa pengertian di atas dapat disimpulkan bahwa Tuhan itu ada. Tuhan itu ada bermacam-macam. Para nabi berdasarkan wahyu menetapkan Tuhan Allah saja yang benar. Adapun Tuhan selainNya tergolong banyak, bisa berupa; tokoh masyarakat, hawa nafsu, patung, berhala dan lainya yang disembah.

Jadi Ilmu ke-Tuhan-an yang dimungkinkan pasti kebenaranya dan sesuai dengan kenyataan, dengan pengetahuan yang pasti, tiada lain adalah penetapan dan peniadaan yang berdasarkan wahyu, karena tidak ada siapapun yang mengetahui hakikatnya kecuali Allah dan para utusanNya. Sementara Allah telah menegaskan tidak ada sesuatupun yang sama denganNya. (QS. 42: 11). Dengan ini menunjukkan tidak ada qiyas dalam masalah Tuhan.

Untuk itu fokus kajian ini adalah Tuhan Allah versi para rasul. pembahasannya meliputi Dzat, nama, sifat, perbuatan dan hak-hakNya yang telah ditetapkan Allah sendiri dalam wahyu dan telah disampaikan para rasul. Adapun 
pembahasan Tuhan selainNya hanya sekilas begitu saja, sekedar penjelasan yang diharapkan bisa menambah kejelasan dari sisi bahwa ajaran para para nabi tentang ketuhanan itu sangat mudah dan tidak membingungkan sementara ajaran selainnya membuat hilang keyakinan atau menambah keraguan.

\section{Ruanglingkup Pemahaman Teologi}

Penulis akan memaparkan secara ringkas tiga pemahaman Teologi yaitu menurut ahli filsafat, ahli kalam dan para rasul:

a. Pemahaman Teologi menurut ahli filsafat

Ahli filsafat dimaksudkan meliputi dua aliran yaitu ahli filsafat murni ( mahdzoh) seperti al-Farabi dan ahli filsafat kebatinan (bâthiniyah). Falsafah bâthiniyyah mencakup; pertama; Râfidhah Isma'iliyah seperti Ibnu Sina, Ikhawnus șafa, dan kedua; Şufiyah Ittihâdiyyah seperti Ibnu Arobî dan Ibnu Sab'în. (al-Tamimi, 1996,13).

Dua hal yang akan dijelaskan di sini; metode dan pemahaman mereka:

1). Metode ahli filsafat dalam memahami teologi

Aristoteles dalam masalah mengenal ketuhanan, ia berkata:

"Sesungguhnya orang yang memulai mengenal ketuhanan, hendaklah Ia menghapus semua ilmu dan keyakinan dari hatinya dan berusaha untuk menghilangkanya sesuai dengan kemampuanya, dan hendaklah ragu dalam segala hal kemudian mencukupkan dengan akal, hayalan dan pemikirannya serta wajib tidak mengimani kecuali sesuatu yang bisa dirasakan”. (alRumyan, 1429, 88).

Dari perkataan Aristoteles dapat diungkapkan dan dianalisis bahwa metode memahami ketuhanan sebagai berikut di antaranya:

a). Pengkosongan hati dari tuhan dan ini menyelisihi fitrah (QS. 7: 172) dan mennjukkan tidak beriman kepada yang gaib yaitu Allah. (QS. 2: 3).

b). Menanamkan keraguan kecuali yang telah ditetapkan akal, dan ini menunjukkan tidak beriman dengan wahyu dan para nabi serta menyombongkan diri. (QS. 2: 34).

c). Menjadikan akal sebagai asas pembahasan teologi bukan wahyu, dan menunjukkan tidak beriman dengan kitab-kitab Allah. (QS. 36: 15). 
2). Pemahaman ahlu filsafat tentang Teologi

Ibnu al-Qaiyim berkata: “ Pengikut Aristoteles, Ibnu Sina dan Al- Bushair alThusi bahwa tauhid adalah menetapkan wujud tanpa dzat dan sifat, bahkan Dia itu wujud secara mutlak tanpa dzat, tidak tegak diatas sifat dan tidak terkhususkan dengan sifat... (1988, 3: 466)

Penjelasan Harras bahwa syirik menurut mereka adalah menetapkan sifatsifat bagi dzat karena ini mengharuskan penetapan tiga yang berbeda yaitu dzat, sifat dan wujud, dan ini mengharuskan banyak sekaligus meniadakan tersebar. Oleh karena itu mereka meniadakan dzat dan sifat. Dan tidak tersisa kecuali wujud tanpa disandari sesuatupun padanya sehingga tidak menjadi wujud nyata. Pada akhirnya mereka mengarah pada suatu perkataan bahwa ilâh itu wujud secara mutlaq dengan syarat mutlaq. Dan ini maknanya sesungguhnya tidak ada Ilâh (Tuhan) dalam kenyataan, adaNya hanya bermuara dalam pikiran. (Harras, 1995, 2: 48).

Adapun adapun ahli falsafah ittihaddiyah, maka tauhid mereka bahwa Sesungguhnya Dia yang maha suci itu adalah dzat yang ada dari semua yang ada. (Ibnu Qaiyim, 1988,3: 466).

Harras menjelaskan bahwa aliran wihdah al-wujûd seperti Ibnu Sab'în, Tilmasânî, Ibnu Araby dan al-Fâriḍî yang mengatakan bahwa Tauhid adalah menetapkan wujud yang ada adalah wujud Allah tidak ada pencipta dan tidak ada yang diciptakan, karena hal ini mengatarkan kepada penetapan yang ada itu dua, jadi yang ada semua ini adalah wujud Allah sebagaimana menyatunya gula dengan air. Maka shirik menurut mereka adalah penetapan ada tuhan dan ada hamba tuhan bahkan mereka katakan al-Qur-'an adalah kitab shirik karena membedakan antara pencipta dan yang diciptakan. (1995, 2: 49-50).

b. Pemahaman Teologi menurut ahli kalam

Ahlu al-kalam adalah Jahmiyyah, Mu'tazilah, Kullâbiyyah, Asyâ'irah dan Mâturîdiyyah. (al-Tamimi, 1996, 13).

Dua hal yang akan dijelaskan di sini; metode dan pemahaman mereka:

1). Metode ahli al-Kalam dalam memahami teologi

Imam Abu al-Hasan al-Ash'ari menyamakan jalan/usul berfikir antara aliran ahli filsafat dan ahli kalam. (al-Ash'ari, 1988: 135). 
Khalifah menjelaskan bahwa ahlu kalam menjadika akal sebagai dasar/sumber ilmu, iman dan al Quran mengikut akal, jadi landasan penetapan dan peniadaan adalah akal wahyu dicocokkan, kalau mencocoki akal diterima sebagai penguat bukan pondasi utama kalau tidak mencocokinya ditolak.( 1996: 99).

Abdullah Ghunaiman menegaskan bahwa mereka menjadikan akal sebagai induk/pokok dalam menetapkan adanya Allah, dibangun di atas pondasi bahwa alam ini baru, kemudian menetapkan sifat Allah, tidak ada dan ada dibangun dengan qiyas aqly kemudian menetapkan kenabian kemudian setelah itu berbicara tentang sam'iyat. Inilah metode Mu'tazilah, Karramiyah, Kullabiyah, As'ariyah kecuali bahwa As'ariyah menempuh jalan ini pada usul I'tiqod ilmiyah bukan amaliyah, adapun Mu'tazilah maka mereka tidak membedakan antara aqidah dan amal dalam qiyas aqly. (alGhunaiman, 1405, 1: 43).

Metode pendidikan tauhid menurut mereka, pertama: Membangun tauhid di atas dasar akal bukan wahyu. Kedua: Ragu adanya Tuhan. Ketiga: Berfikir atau niat berfikir tentang Tuhan. Keempat: menyimpulkan tentang Tuhan. Sementara kelompok yang Lain membangun tauhid di atas dasar wajib taqlid kepada orang-orang terdahulu. (Nurul yaqin, 2020: 45).

2). Pemahaman Ahlu al-kalam tentang Teologi

Versi Jahmiyyah bahwa tauhid adalah membuang semua sifat untuk Allah karena ini mengantarkan kepada penyerupaan Allah dengan Makhluk, contoh ketika ditetapkan sifat mendengar bagi Allah, makhlukpun mendengar berarti tidak mentauhidkan Allah karena masih menyamakan Allah dengan makhluk. Maka syirik menurut mereka adalah menetapkan sifat bagi Allah. (Harras, 1995, 2: 50-51).

Ibnu Taimiyah menyebutkan bahwa mereka itu tiga tingkatan, yang pertama; Jahmiyah Ghulat yaitu yang meniadakan nama dan sifat bagi Allah dan menjadikan nama-nama Alah itu majaz. Yang kedua; Jahmiyah yang menetapkan nama-nama Allah al-Husna secara umum dan menjadikan kebanyakannya majaz, Sementara dalam masalah sifat mereka tiadakan. Mereka ini adalah Mu'tazilah. Ketiga; Segolongan orang-orang yang menetapkan sifat yang berbeda dengan jahmiyah tapi ada keserupaan dengan 
mereka dalam sebagian sisi, mereka disebut jahmiyah karena ada kesamaan dalam masalah meniadakan sifat.

Kelompok ketiga ini ada tiga golongan; yang pertama; menetapkan sifat Allah dalan al-Qur'an bukan hadith. Kedua; menetapkan sifat khabariyah secara umum dan meniadakan sebagian yang lain yang ada pada nash, mereka seperti Abu Muhammad bin Kullab dan orang-orang yng mengikutinya seperti Abu al-Hasan al-Ash'ari. Ketiga menasabkan kepada golongan kedua, namun keaadaannya mendekati pemikiran mu'tazilah mereka banyak meniadakan sifat dan menyelisihi tokohnya, dan di antara mereka ada berimbang antara menetapkan dan meniadakan namun banyak kontradiksi di ataranya seperti al-Ghozali dan al-Razi. (Muhammmad Nur,1995, 1: 46-46).

Ibnu Hajar mengungkapkan bahwa Tauhid dalam pandangan mu'tazilah adalah meniadakan sifat bagi Allah, karena menetapkan sifat bagiNya mengharuskan tashbîh (menyamakan dengan selainNya) dan siapa saja menyamakan Allah dengan makhluNya adalah musyrik. Mereka mencocoki Jahmiyyah dalam masalah meniadakan (Sifat). (al-Asqolany,1986, 13: 357). Versi Mujassimah dan Musyabbihah yaitu yang menyamakan sifat Allah dengan sifat makhluk seperti tangan Allah sama dengan tangan manusia. Orang pertama mengatakan yang demikian itu adalah Muqâtil bin bin Sulaimân (w. 150, H.) yang menghadang pemikiran Jahm bin Şafwân (w.124, H.) atau Jahmiyah di Khurasân akhirnya terjatuh dalam sikap berlebih-lebihan dalam menetapkan sifat Allah sampai menetapkan Jismun bagi Allah (Ash'ari, 1990, 1: 283; Dzahabi, t.th, 1: 160). Penjelasan alDhahabî dari imam Ibnu Hibbân: Sebabnya dia belajar ilmu al-Qur'an dari yahûdi dan Nașârâ akhirnya menyamakan Allah dengan makhluk dan mendustakan hadits. (Dzahabi, t.th. 1: 175).

c. Pemahaman Teologi menurut para rasul

Dua hal yang akan dijelaskan di sini; metode dan pemahaman mereka:

1). Metode memahami teologi

Metode pendidikan tauhid menurut para nabi dan rasul tiada lain kecuali dengan wahyu. Berkata Imam Al-Sijzî:”Sepakat orang-orang salaf bahwa mengenal Allah dengan akal mungkin, tidak wajib dan sesungguhnya 
yang wajib itu mengenal dengan dalil Naqli karena ancaman berkaitan dengan itu, Allah berfirman:

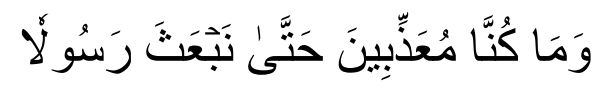

"Dan Kami tidak mengazab sebelum Kami mengutus seorang rasul". (QS. 17:15), Kita telah tahu akal itu telah ada sebelum datangnya rasul, dan adzab terangkat dari orang berakal, sementara kita dapati menyelisihi rasul dan nash-nash berhak diadzab, maka jelaslah hujjah itu tiada lain kecuali dalil naqli bukan lainnya. Sungguh telah disepakati bahwa seseorang kalau berkata:" akal tidak hujjah pada dzatnya hanya sebagai alat untuk mengenal hujjah, tidaklah dia itu kafir dan tidak pula fasik, Tapi kalau berkata al-Qur,an itu tidak hujjah maka dia itu kafir halal darahnya. Maka dengan itu terbukti bahwa hujjah yang pasti itu adalah dali naqli tidak yang lain”. (al-Sijzi,1994: 93-94).

Menurut Abdullah al-Ghunaiman bahwa tidak ada jalan untuk mengetahui kewajiban kecuali dengan mengikuti wahyu yang telah dibawa nabi Muhammmad, Maka wajib wahyu itu diikuti dan dijadikan sebagai pondasi dan asas dalam mengenal ibadah, iman kepada Allah, rasul, malaikat, kitab dan hari akhir, serta iman kepada Nama- nama Allah dan sifat-sifatNya. (al-Ghunaiman,1405, 1: 43).

Berkata Imam Abu al-Hasan al-Ash'arî:

"Sepakat para ulama', mensifati Allah dengan apa yang ditetapkan Allah dan yang ditetapkan utusanNya, tanpa membantah, tanpa membagaimanakan dan sesungguhnya mengimani adalah suatu kewajiban dan meninggalkan takyîf adalah harus/wajib". (al-Ash'ary, risâlah 1988: 236). Di tempat lain mengatakan:" Tidaklah para ulama' mengunakan pertanyaan kaifa/bagaimana (untuk sifat Allah) dan lima / kenapa (untuk perbuatan Nya) karena yang demikian itu adalah bid'ah". (al-Ash'ary, 1990, 1: 347).

2). Pemahaman para rasul tentang Teologi

Berdasarkan istiqra' dalil- dalil tauhid terbagi menjadi dua yaitu:

a). Tauhid Qouly I'tiqâdy atau Tauhid 'Ilmy Khabary atau Tauhid ma'rifah wal Ithbât yang mencakup Tauhid Rubûbiyyah dan Tauhid asmâ' was- Sifât. (Harras, 1995, 2: 55) 
Menurut Ibn Baz bahwa tauhid rububiyyah adalah mengesakan Allah pada perbuatan-perbuatanNya, yaitu mengimanai bahwa Allah itu adalah Pencipta, Pemberi rizki, Pengatur semua urusan makhlukNya, Yang mengurusi keadaan mereka di dunia dan di akhirat, yang tidak ada sekutu baginya sebagaimana firman Allah:

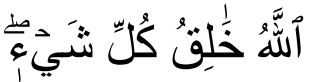

Allah Pencipta segala sesuatu.(QS. 39:62).

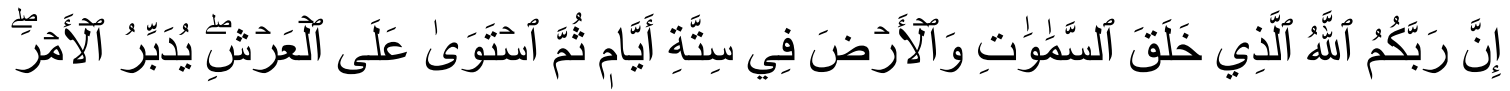

Sesungguhnya Tuhan kamu ialah Allah Yang menciptakan langit dan bumi dalam enam masa, kemudian Dia bersemayam di atas 'Arsy untuk mengatur segala urusan. (QS.10:3).

Tauhid ini sungguh telah diakui orang-orang musyrik, penyembah patung, sekalipun kebanyakan mereka mengingkari adanya hari kebangkitan. Dan tauhid ini tidak memasukkkan mereka ke dalam Islam karena mereka syirik dalam beribadah, mereka menyembah berahala dan patung malaupun sambil menyembah Allah dan mereka tidak beriman kepada nabi Muhammad. (Uthman, 2006: 54-55).

Adapun Tauhid asma wa sifat, Abdul Aziz bin Baz menjelaskan yaitu mengimani setiap nama-nama dan sifat-sifat Allah yang terdapat dalam al-Qur'an dan as-Sunnah as-Shahihah. Menetapkannya untuk Allah di atas betuk yang layak untukNya, tanpa menyelewengkan, membuang maknanya dan tanpa menentukan bentuknya dan menyerupakannya. Sebagaimana Allah berfirman:

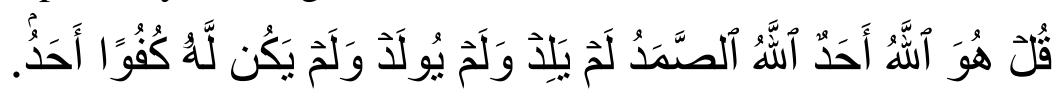

Katakanlah: "Dialah Allah, Yang Maha Esa. Allah adalah Tuhan yang bergantung kepada-Nya segala sesuatu. Dia tiada beranak dan tidak pula diperanakkan, dan tidak ada seorangpun yang setara dengan Dia". (QS. 112: 1-4).

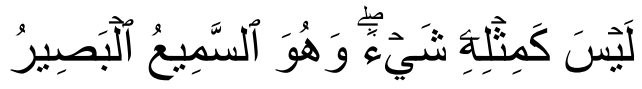

Tidak ada sesuatupun yang serupa dengan Dia, dan Dialah yang Maha Mendengar dan Melihat. (QS. 42:11)

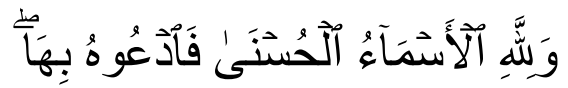


Hanya milik Allah asmâ-ul husna, maka bermohonlah kepada-Nya dengan menyebut asmâ-ul husna itu. (QS. 7:180).

Dia berfirman:

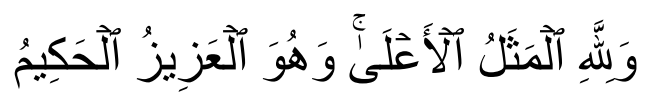

Dan Allah mempunyai sifat yang Maha Tinggi; dan Dialah Yang Maha Perkasa lagi Maha Bijaksana. (QS. 16: 60).

Ayat-ayat semakna dengan ini banyak, wal mathalul a'lâ maksudnya sifat yang tinggi yang tidak ada sedikitpun kekurangan.

Inilah perkataan ahlus-sunnah wal-Jama'ah, dari para shahabat dan pengikut mereka dengan baik. Mereka memberlakukan ayat-ayat dan hadith-hadits sifat sebagaimana datangnya, menetapkan maknanya dengan penetapan yang berlepas diri dari penyerupaan, mensucikan Allah dari penyerupaan dengan makhlukNya dengan pensucian yang berlepas diri dari membuang maknanya. Dan dengan inilah perkataan mereka itu sesuai dengan semua dalil al-Qur'an dan as-Sunnah, tegak hujjah ini kepada orang-orang yang menyelisihi mereka. Mereka itu disebut dalam firman Allah:

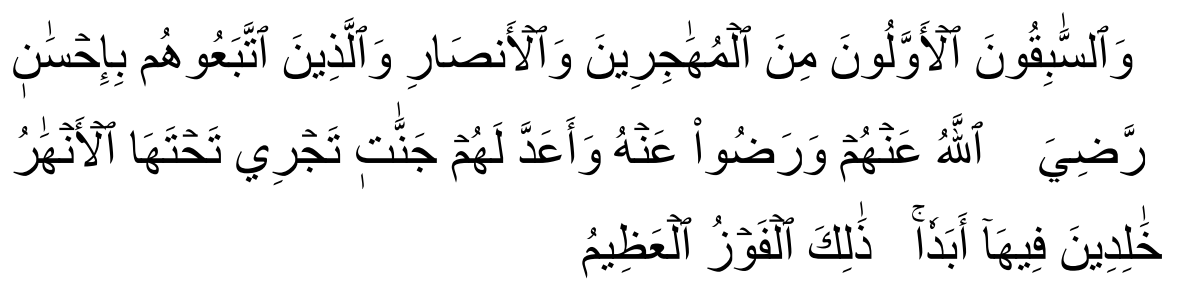

Orang-orang yang terdahulu lagi yang pertama-tama (masuk Islam) dari golongan muhajirin dan anshar dan orang-orang yang mengikuti mereka dengan baik, Allah ridha kepada mereka dan merekapun ridha kepada Allah dan Allah menyediakan bagi mereka surga-surga yang mengalir sungai-sungai di dalamnya selama-lamanya. Mereka kekal di dalamnya. Itulah kemenangan yang besar.(QS. 9: 100). (Uthman, 2006: 55-57).

Syeikh as-Sa'dy berkata:"Secara global dalam hal ini orang terkelompokkan menjadi tiga: mukmin muwahhid, mushabbih dan muaţ̦il. Maka mukmin muwahhid adalah orang yang mensifati Allah 
dengan sifat yang Allah tetapkan untuk diriNya dan yang telah disifatkan oleh utusanNya, berupa sifat sempurna yang sesuai dengan kemulyaan dan keagunganNya, tanpa mentamthîl dan mentashbîh, serta tanpa mentahrîf dan menta'ţîl sedikitpun dari sifat-sifat tersebut. Musabbih yaitu orang yang menyamakan sifat-sifat Allah dengan sifat-sifat makhluk atau orang yang menjerumuskan dirinya untuk mengetahui hakikat sifat-sifat Allah yang tidak ada seorangpun yang mengetahuinya kecuali Allah. Sementara muațtil adalah orang yang meniadakan sesuatu dari sifat-sifat Allah. Masing-masing dari muattil dan musabbih telah terbentengi dari mengenal Allah sebagaimana mestinya dan terfitnah dengan membebankan diri di luar kemampuannya dan menyeleweng dari nas-nas wahyu.

Sebagaimana dia membatalkan wahyu maka dia telah membatalkan tuntutan akal dan fitrah yang tidah pernah mengalami perubahan, dengan itu menunjukkan mereka tidak mempunyai hujjah aqli dan hujjah naqli.

Allah telah memberi petunjuk orang-orang ahlus-sunah wal-jama'ah untuk mengukuti kebenaran dari Allah dan RasulNya, serta hujjah aqliyah yang bisa difahami oleh ulul albab, yang demikian itu tanpak dengan mentadabburi berbagai masalah, dalail dan penelitian yang ada di aliran-aliran lain”. (Harras, 1995, 2:63).

Adapun aliran Mujassimah (Musabbihah) sungguh bukan ajaran para rasul, yang pertama mengatakan yang demikian itu adalah Muqâtil bin bin Sulaimân (w. 150, H.) yang menghadang pemikiran Jahm bin Şafwân (w.124, H.) di Khurasân akhirnya terjatuh dalam sikap berlebih-lebihan dalam menetapkan sifat Allah sampai menetapkan Jismun bagi Allah. (Dzahabi, Tdzkiroh, t.th. 1:160; al-Ash'ari, 1990, 1: 283). Imam Abu Hanîfah (w. 150, H.) berkomentar telah datang dari Mashrik dua pemikiran yang busuk; Jahm yang meniadakan sifat bagi Allah, dan Muqâtil yang menyerupakan/menyamakan sifat Allah dengan Makhluq. Wakî’ bin Jarrâh berkomentar tentang Muqâtil; “dia adalah pendusta". (Dzahabi, Mizan, t.th. 4:173). Penjelasan alDhahabî dari imam Ibnu Hibbân: Sebabnya dia belajar ilmu al-Qur'an 
dari yahûdi dan Nașârâ akhirnya menyamakan Allah dengan makhluk dan mendustakan hadits .(Dzahabi, Mizan, t.th. 4:175).

b). Tauhid Fi'ly atau Tauhid Ţalaby atau Tauhid Ilahiyyah atau Tauhid 'Ibâdah. (Harras, 1995, 2: 55)

Tauhid terkait dengan ini diistilahkan dengan Tauhid Ilahiyah/ Uluhiyyah/Ibadah/Ţalab wal qașdu. Ini berhubungan dengan niat, keinginan, perbuatan dan tujuan hamba; berupa pelaksanaan ibadah hanya untuk Allah sebagai hak-hakNya tidak boleh untuk selaiNya.

Menurut Abdul Aziz bin Baz bahwa Tauhid uluhiyah inilah yang diingkari orang-orang musyrik sebagaimana Allah telah menyebut dalam firmanNya:
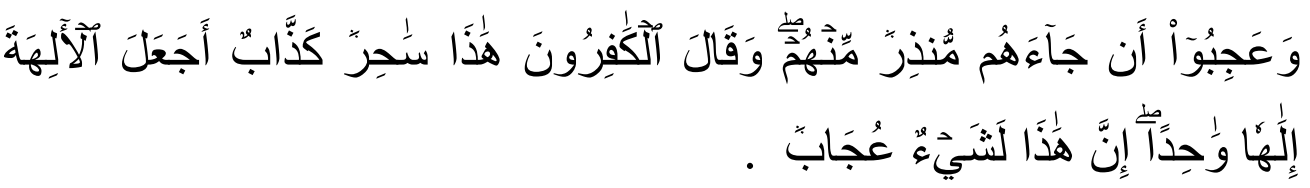

Dan mereka heran karena mereka kedatangan seorang pemberi peringatan (rasul) dari kalangan mereka; dan orang-orang kafir berkata: "Ini adalah seorang ahli sihir yang banyak berdusta". Mengapa ia menjadikan tuhan-tuhan itu Tuhan (Ilah) Yang Satu saja? Sesungguhnya ini benar-benar suatu hal yang sangat mengherankan. (QS. 38:4-5).

Dan ayat-ayat seperti ini banyak. Tauhid ini mengandung pemurnian ibadah hanya untuk Allah saja, dan beriman bahwa Dialah yang berhak diibadahi dan sesungguhnya ibadah kepada selainNya adalah salah. Ini adalah makna la ilha illah yang artinya tidak ada Ilah yang berhak diibadahi kecuali Allah sebagaimana firman Allah:

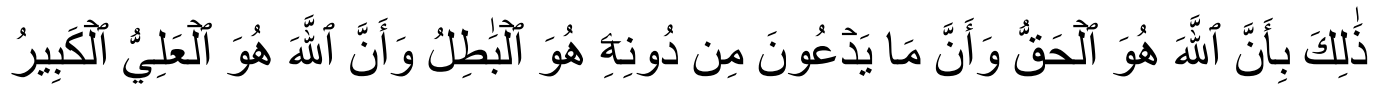
Yang demikian itu, adalah karena sesungguhnya Allah, Dialah Yang Haq dan sesungguhnya apa saja yang mereka seru selain dariNya, itulah yang batil, dan sesungguhnya Allah, Dialah Yang Maha Tinggi lagi Maha Besar. (QS. 22:62; Uthman, 2006: 47).

\section{Kesimpulan}

Dari uraian di atas dapat disimpulkan sebagai berikut; 
1. Ilmu ketuhananan adalah Ilmu yang paling tinggi kedudukannya, di atas ilmu-ilmu lainnya karena pembahasannya tentang pencipta makhluk bukan makhluk.

2. Tuhan itu adalah $R a b b$ dan Ilâh, yang benar tidak lain kecuali Allah. SelainNya adalah tuhan yang salah.

3. Ilmu ketuhanan yang benar adalah ilmunya para rasul bukan ahli filsafat karena pengetahuannya sesuai dengan kenyataan dengan pengetahuan yang pasti, tidak berdasar prasangka dan keraguan.

4. Berdasarkan istiqro' ulama bahwa al-Qur'an dan al-Sunnah telah lengkap dan sempurna membahas keTuhanan yang bisa mengantarkan manusia kepada keridhoan Allah dan intinya adalah mentauhidkan Allah.

5. Ilmu ketuhanan itu meliputi pengetahuan bahwa pertama: Allah itu satu-satunya pencipta, pemilik dan pemelihara makhluk yang diistilahkan dengan Tauhid Qouly I'tiqâdy atau Tauhid 'Ilmy Khabary atau Tauhid ma'rifah wal Ithbât atau tauhid rububiyah. Kedua bahwa Allah itu satu-satunya yang berhak diibadahi/ disembah diistilahkan dengan Tauhid Fi'ly atau Tauhid Ţalaby atau Tauhid Ilahiyyah atau Tauhid 'Ibâdah.

\section{Daftar Pustaka}

Ash'arî, A. bin I. 1988. Risâh Ilâ Ahli As-Tsagr, Beirût: Muassasah al-ulûm al-Qur'ân 1990. Maqâlât al-islâmiyîn wa-ikhtilâf al-muşallîn, Beirût: al-Maktabah al'așriyah

Barjas, A bin S. 2005. Al Mu'taqod al Sahih al wajib 'ala kulli muslim I'tiqaduhu. Al

Qahirah: Dar al minhaj

Asqolani (al). A. 1988. Fath al-Bârî bi-Sharh Șahîh al-Bukhârî, al-Qâhirah: Dâr al-Raiyân

Dzahabi, M. bin A. 1374. Tdzkirotul Huffâdz, Makkah: Dar al-Fikr al-'Arroby 1963. Mîzân al-'itidâl, : Dar al-Fikr

Ghunaiman (al), A bin M. 1405. Sharhu kitab tauhid min sahihi al-Bukhori, Madinah:

Maktabah al-Dar

Harras M.K. 1995. Sharh Al-Qașîdah Al-Nûniyah, Beirut: Dar al-kutub al-'Ilmiyah

Hasan, A. A. 1992. Fathul Majid, Beirut: Dar al-Fikr

Jauziyah, I. Q. 1998. Madarij al-Salikin, Beirut: Dar al-kutub al-'Ilmiyah 1994. Miftâh dâr al sa'âdah almanshur wilayah ahli ilmi wa al wilayah, Riyadh: Zamzam 
Tim Penyusun Kamus Pusat pembinaan dan Pengembangan Bahasa Departemen Pendidikan dan Kebudayaan. 2018. Kamus Besar Bahasa Indonesia, Jakarta: Balai Pustaka

Khalîfah, M. T. 1996. Mu'taqod Ahlissunnah Waljama'ah Fi Tauhid Asma' Wassifât, Beirût: Dar al-îlâf al-dauliyah . 1996. Mu'taqad Ahlissunnah Waljama'ah Fi Asmâ Allah Al-Husnâ, Beirût: Dar al- îlâf al-dauliyah 1997. Maqaltut ta 'til wa Ja'du bin Dirham, Madinah

Lâlikâî, Q. bin H. 1994. Sharhu Ușûl I'tiqâd Ahl Al-Sunnah Wal-Jamâ'ah, Riyad: Dâr alŢayyibah

Manḍûr (al), M bin M. 1990. Lisan al-Arab, Beirût: Dar al-Șâdir

Muhammad Nur, K bin M. 1995. Manhaj ahli sunnah wa al jama'ah wa manhaj al asha'irah fi tauhid Allah, Saudi: maktabah al Guroba' al Athariyah

Nurul yaqin. 2020. Konsep Tauhid menurut Abdurrahman bin Sa'di dalam kitab taisir kaim rahman fi tafsir al-kalam al manan. Jawa Timur: Sahabat pena kita

Sa'dî, A. bin N. 2002. Taisîru al-Karîm al-Rahmân fi tafsîr kalâm al-Mannân, Beirût, Muassasah al-Risâlah

Sijzi (al) U bin S. 1994. Risalah ila ahl al-Zabîd fi al-Rad 'ala man Ankara al-Harfa wa al-șaut, al-Riyâḍ: Dar al-Râyah

Suyûtî (al), J. A. 1990. Al-Durru al-Mantsûr fi al-Tafsîr al-Ma'tsûr, Bairût: Dâr al kutub al-'ilmiyah

Rumyâni (al), A binM. 1429. Al-Juhûd al-da'awiyyah wal-'ilmiyyah li al-Shaikh Abdurrahman al-Sa'di, Makkah al- Mukarromah: Dar Thoyyibah

Uthaimin, M. bin S. 1424. Al Usul min ilmi al usul. Al-Qohiroh: Dar al-Aqidah

Uthman, K bin M. 2006. Tahshilul intifa' bimatnil aqidah tahawiyayah, Mesir: Darul Athar 


\section{Suharsono}

138 Volume 8 No. 1, 1 Maret 2022 